\title{
Technology and raw material sources of pottery from Mulyosari Site based on petrographic analysis
}

\section{Teknologi dan sumber bahan gerabah Situs Mulyosari berdasarkan analisis petrografi}

\author{
Putri Novita Taniardi ${ }^{1}$, Anggara Nandiwardhana ${ }^{2}$, Maulana Ainul Yaqin ${ }^{3}$, and \\ Citra Iqliyah Darojah ${ }^{2}$ \\ Regional Agency for Archaeological Research in D.I. Yogyakarta Province 1, \\ Association of Indonesian Archaeologists 2, Alumni of Universitas Gadjah Mada 3 \\ putri.taniardi@gmail.com
}

\begin{tabular}{|c|c|}
\hline & ABSTRAK \\
\hline $\begin{array}{l}\text { Kata Kunci: } \\
\text { Gerabah; } \\
\text { Situs } \\
\text { Mulyosari; } \\
\text { petrografi; } \\
\text { sumber } \\
\text { bahan; } \\
\text { teknologi }\end{array}$ & $\begin{array}{l}\text { Fragmen gerabah merupakan temuan hasil ekskavasi di Situs Mulyosari yang } \\
\text { paling dominan di antara temuan lainnya sejak tahun } 2018 \text { hingga tahun } 2019 . \\
\text { Oleh karena itu, analisis fragmen gerabah perlu dilakukan terutama yang } \\
\text { berasosiasi langsung dengan struktur megalitik. Analisis petrografi yang } \\
\text { diterapkan dalam penelitian ini bertujuan untuk mengetahui teknologi dan } \\
\text { sumber bahan fragmen gerabah. Analisis diperlukan untuk mengetahui } \\
\text { apakah gerabah tersebut dibuat secara lokal atau didatangkan dari luar. } \\
\text { Analisis dilakukan pada sejumlah sampel gerabah dari kotak ekskavasi. } \\
\text { Sampel dipilih tidak secara acak, namun berdasarkan kriteria khusus. Hasil } \\
\text { analisis menunjukkan bahwa sumber bahan yang digunakan dalam } \\
\text { pembuatan gerabah berada di dalam formasi geologi wilayah penelitian } \\
\text { yakni, formasi Sukamade, Merubetiri, Batu Ampar, dan Anggota } \\
\text { batugamping Merubetiri. Selain itu, hasil analisis juga menunjukan teknologi } \\
\text { pembuatan gerabah yang tergolong maju, yakni dengan roda putar dan } \\
\text { pembakaran terbuka pada suhu mencapai } 400 \text { derajat Celsius. }\end{array}$ \\
\hline
\end{tabular}

\section{ABSTRACT}

Keywords:

Pottery;

Mulyosari

Site;

petrography;

material

source;

technology
Since the research in 2018 until 2019, pottery sherds are the most dominant artifact from Mulyosari megalithic site amongst other. Hence, analysis conducted towards pottery directly associated with the megaliths are important. Petrographic analysis that was applied in this research is aiming to understand the technology and the material source of pottery at Mulyosari Site. It is necessary to know whether the pottery is locally made or imported from other region. Petrographic analysis was carried out to several excavated pottery samples. All the samples were not randomly chosen; instead they were based on specific character of pottery sherds. The result of analysis shows that the source of pottery material located within geological formation of researched area comprises Sukamade, Merubetiri, Batu Ampar, and Merubetiri limestone. The result of analysis also shows advanced pottery making technology using spinning wheel and open firing at 400 Celsius degrees.

\begin{tabular}{|c|c|c|c|}
\hline$\sum^{9} 1$ & & $\begin{array}{l}\text { VOLUME } \\
\text { DOI } \\
\text { VERSION } \\
\text { WEBSITE }\end{array}$ & $\begin{array}{l}: 41 \text { No.1, May 2021, 15-34 } \\
: \underline{10.30883 / \text { iba.v4li1.610 }} \\
: \text { English (translated) } \\
: \text { berkalaarkeologi.kemdikbud.go.id }\end{array}$ \\
\hline ISSN: 0216-1419 & E-ISSN: 2548-7132 & (cc) & $\begin{array}{l}\text { This work is licensed under a Creative Commons Attribution-Non } \\
\text { Commercial-ShareAlike } 4.0 \text { International License }\end{array}$ \\
\hline
\end{tabular}




\section{INTRODUCTION}

Pottery sherds of the Mulyosari Site is the dominant artifact obtained during research period from 2018 to 2019 by the Regional Agency for Archaeological Research in D.I. Yogyakarta Province. It is found within the context of megalithic structures comprises circular stone arrangements and dolmen. Dolmen widely known as part of burial rites. Hence, the presence of pottery sherds shows indications of the ritual process or the function as burial goods. The existence of pottery sherds that have important value in the ritual process or burial goods in megalithic culture, raises questions regarding the origin of the pottery. Therefore, petrographic analysis is needed as an initial step to show minerals from the raw material sources and pottery making technology. The analysis result will provide information on whether the pottery found at Mulyosari Site is locally produced or imported from another region.

Megalithic culture research in Banyuwangi began with a survey in Afdeling Mulyosari, Malangsari Plantation, Kecamatan Kalibaru, Kabupaten Banyuwangi. Based on survey result, the Afdeling Mulyosari covered 156.5 ha. The area is divided into five sectors, Sector I, Sector II, Sector III, Sector IV, and Sector $\mathrm{V}$. The sector division is necessary to integrate mapping process in the archaeological research. The mapping process of the site is conducted in regards with the rivers as natural boundaries. The survey results were followed up by excavations within the Afdeling Mulyosari area. Excavations were conducted in Sector I, Sector II, and Sector V by opening seven excavation boxes. Excavations in Sector I conducted in S1T2, U2T1, U2T2, S15T14, S14T13, and S14T14. Excavations in Sector II conducted in U7B10, while excavations in Sector V were conducted in S1B1 (Taniardi et al., 2019).

Excavations result in Sector I comprises archaeological data consisting of structures and artifacts. The structures found in S1T2, U2T1, and U2T2 are dolmens. While the structures found in S15T14, S14T13, S14T14 are stone chambers. The artifacts found in S1T2 consist of pottery sherds, beads, stone and metal fragments. Pottery sherds found in association with burned soil used as samples in dating analysis. Dating samples were also taken from charcoal associated with pottery sherds and burnt pottery sherds. The samples were taken from S1T2 soil layer, namely Spit 9, 10, 11, and 13. Carbon dating analysis of charcoal samples taken from Spit 10 and 11 was conducted by Beta Analytic (Miami). Carbon dating analysis results are 323-424 AD, 1627-1526 cal BP, 1720+/-30 BP (Spit 10 pottery sherd sample); 1697-1530 cal BC, 3646-3479 cal BP, 3390+/- 30 BP (Spit 10 charcoal sample); 322- 417 cal AD, (1628-1533 cal BP), $1730+/-30 \mathrm{BP}$ (Spit 11 charcoal sample). The results show that the dating from Spit 10 pottery sherd sample were linear with the dating from Spit 11 charcoal sample, while the charcoal sample from Spit 10 within the same context with the pottery sherd shows older dating result (Taniardi et al., 2019).

Based on excavations result in Sector I and Sector $V$ there were at least three megalithic characters from around 4 th century AD. The first character is dolmen with circular stones arrangement. The second character is stone chamber formed by flat stones arrangement. The third character is dolmen without circular stone arrangement (Taniardi et al., 2019). The research result of Mulyosari Site regarding the presence of pottery in megalithic sites possibly in accordance with Solheim statement regarding burial and religious rites (Solheim, 1990). Religion or belief correlate with the megalithic practices. It also associated with the ritual to respect ancestral spirits (Gede, 2013). Furthermore, not only in Mulyosari Site, pottery sherds are also found within the context of megalithic sites in Central 
Sulawesi, East Nusa Tenggara, Sumatra, and East Java (Kusumawati, 2011).

Pottery sherds from several sites in Indonesia have been analyzed using petrographic methods. These sites include Ranu Bethok and Ranu Grati (Kasnowihardjo, 2012) , Tron Bon Lei Site, Tabubung Cave, and Lerabaing Village (Nandiwardhana, 2017). The results of petrographic analysis on these sites able to show the similarity of materials, production sites, distribution, location of material sources, and technology. These aspects determine the provenance of pottery sherds in an archaeological site (Ownby et al., 2017).

As well as petrographic analysis conducted at some of these sites, petrographic analysis is also applied to pottery sherds of Mulyosari Site. Petrographic analysis considers the data transformation factors influenced by plantation activities as the location of Mulyosari Site. The condition affects the position of pottery sherds that may undergo intrusion process. The application of petrographic analysis, also the important value of pottery sherds association with megalithic structures, will be described through this paper. This paper also explains the possible technology of pottery making, the possible location of the raw material sources, and whether the pottery found on the Mulyosari Site was made locally or imported from another region.

\section{METHODS}

A method that can be used to analyze pottery are determined by the purpose of the analysis itself. Some pottery analysis includes thin section, petrographic analysis, textural analysis, heavy mineral analysis, and compositional analysis. In addition, there are analyses using Scanning Electron Microscope (SEM), XRD (X-ray Diffraction), and XRF (X-ray Fluorescence) (Orton et al., 1993). Considering the various methods of pottery analysis available, this study applies petrographic analysis with samples in the form of thin section.

Petrographic analysis is strongly related to geological conditions. Geological conditions reveal possible sources of clay and other materials. Thus, the role of geological maps in petrography analysis is very important (Fatmarani, 2016; Nandiwardhana, 2017). Geological map is also an important reference to recognize mineral inclusion obtained by point counting technique (Mahirta, 2003).

The analytical methods used in this study are macroscopic and microscopic. Macroscopic analysis is done through the observation of shapes, colours, and decorative varieties, while microscopic analysis is done through the observation of shapes, colours, and density. Microscopic analysis of pottery sherd samples has the primary purpose to determine minerals in pottery sherds samples. The sample was not randomly selected, instead based on the quality of the pottery sherds. The selected pottery sherds taken from S1T1, S14T14, S14T13, and S15T14 have special features and have enough material for making thin-sections observation. Pottery fragment samples are selected from both surface spits $(0-100$ $\mathrm{cm})$ and deep spits $(100-170 \mathrm{~cm})$. The determination of the spit category is based on the presence of a feature layer (lenses) evenly in the four excavation boxes.

The total number of pottery sherds in the four excavation boxes was 7346 pieces. Based on this number, 10 pottery sherds consisting of 6 main samples and 4 comparison samples were selected. Comparison samples were selected based on macroscopic observations that showed possible characteristics of modern pottery. These characteristics are shown by the level of vitrification process, a very tight appearance of cross-sectional slices, and mineral components that are almost invisible to the naked eye. Modern pottery sherds come from the 
disturbed layer of the excavation box.

The main sample was selected from pottery sherds based on macroscopic observations. Pottery sherds have special characteristics such as temper conditions that show irregular minerals, cross-sectional slice colors that show dark and light differences, decorative patterns with motifs representing the overall findings, a smooth cross-sectional texture both on the outside and on the inside, and the position of the findings of the deep spit $(100-170 \mathrm{~cm})$. Temper is a non-plastic inclusion that is added to clay intentionally to solidify the clay before it is formed (Department of Archaeology University of York, 2000).

Petrographic analysis of pottery samples is carried out in two stages. The first stage is to create samples in the form of thin sections. It was conducted at the Geological Laboratory of Pembangunan Nasional University in Yogyakarta. The thin section has a size of $3 \mu \mathrm{m}$ based on method written by Patrick Quinn in the Ceramic Petrography. The second stage is the observation of thin sections, conducted in the Archaeological Laboratory of the Archaeological Department of Universitas Gadjah Mada using the Polarizing Microscope Olympus CX-31. Macroscopic and microscopic analyses were conducted to observe the pottery structure (Orton et al., 1993). Observation criteria include the similarity of mineral content type, grain size, number of grains, density between minerals, and clay line or streak. Streak commonly referred to clay line, in contrast to streak that means stroke or scratch in Geological terms. Comparison of mineral types and sample characteristics both macroscopically and microscopically are used to look for possible techniques for pottery making, uniformity, diversity, and location of material sources.

\section{RESEARCH RESULTS}

\section{Macroscopic Analysis Results}

Pottery sherds are commonly found in conditions coated by thick clay. The handling of pottery sherds is carried out in the laboratory by sorting and identifying the size, the sherd parts, the decorative motifs, and the firing rates. Measurements are performed using Vernier Caliper to determine the length, width, and thickness. The measurement results can be seen in Table 1.

Table 1. Macroscopic measurement information of pottery samples

\begin{tabular}{lllllll}
\hline \multirow{2}{*}{ No } & \multirow{2}{*}{ Sample } & Spit & \multicolumn{5}{c}{ Dimension } & \multirow{2}{*}{ Description } \\
\hline 1. & S1T2-6 & 6 & 4 & 3.1 & 0.4 & Comparison \\
\hline 2. & S1T2-11 & 11 & 5 & 3.7 & 0.6 & - \\
\hline 3. & S1T2-13 & 13 & 3.2 & 2.3 & 1.1 & - \\
\hline 4. & S1T2-16 & 16 & 1.8 & 1.5 & 0.6 & Comparison \\
\hline 5. & S14T13-4 & 4 & 2.6 & 2.9 & 0.9 & Comparison \\
\hline 6. & S14T13-8 & 8 & 3.9 & 3.4 & 0.8 & Comparison \\
\hline 7. & S14T14-15-a & 15 & 2.4 & 2 & 0.8 & - \\
\hline 8. & S14T14-15-b & 15 & 6.1 & 3.1 & 0.3 & - \\
9. & S15T14-13-a & 13 & 3 & 1.9 & 0.7 & - \\
10. & S15T14-13-b & 13 & 3.6 & 1.8 & 0.6 & - \\
\hline Source: Anggara Nandiwardhana & & & & &
\end{tabular}


Pottery sherds of Mulyosari Site have many variations, including decorative patterns, colours, shapes, and firing rates. Decorative patterns on pottery fragments show techniques variations and manufacturing processes. For example, the technique of spinning wheels that produce decorative patterns tend to be neat and embossed (see Figure 1). The spinning wheel technique also appear in observation of striation patterns on plain and decorative pottery sherds taken form S14T13. The spinning wheel technique forms embossed and line patterns that appear inline and aligned (see Figure 1). Apart from that, incised geometric

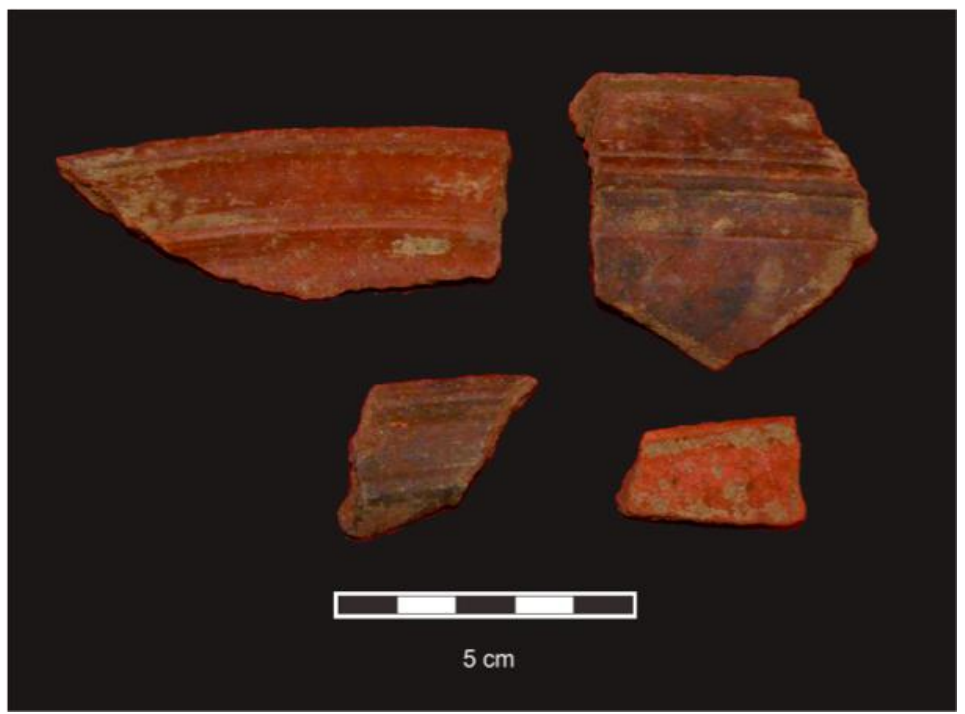

Figure 1. Pottery sherds indicates decorative patterns, modern manufacturing techniques from S14T13

(Source: Regional Agency for Archaeological Research in D.I. Yogyakarta Province)

decoration motifs are seen on several pottery sherds in a fragmentary condition of S1T2 (see Figure 2), while stamped and incised geometric decoration motifs are seen on pottery sherds of S15T14 (see Figure 3). In general, geometric decoration patterns on pottery sherds still cannot show the whole type of pottery decoration motifs.

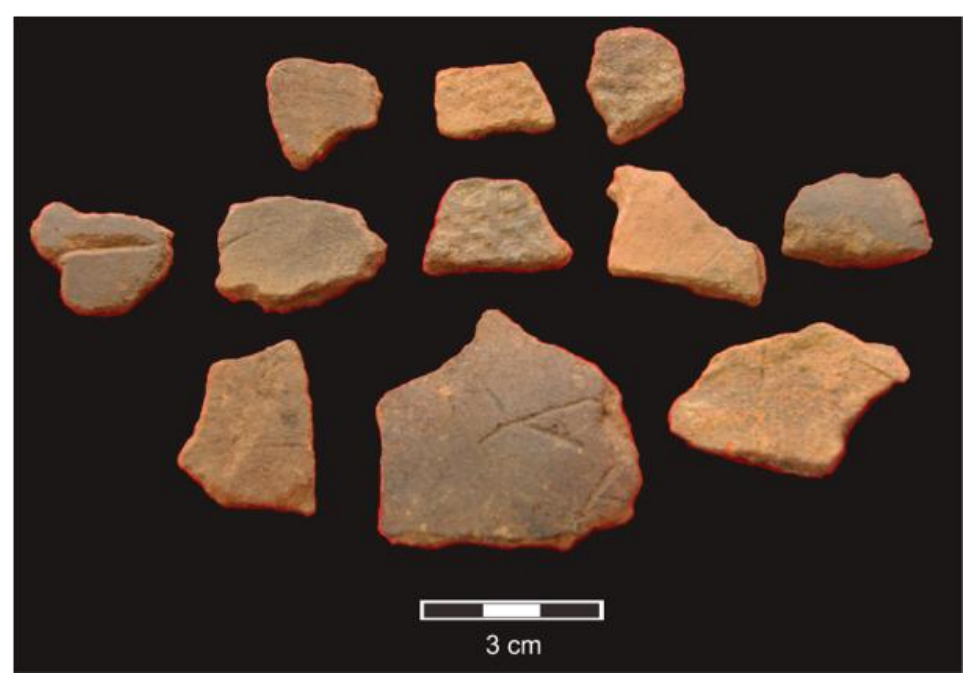

Figure 2. Several decoration patterns of various motifs from pottery sherds S1T2 (Source: Regional Agency for Archaeological Research in D.I. Yogyakarta Province) 


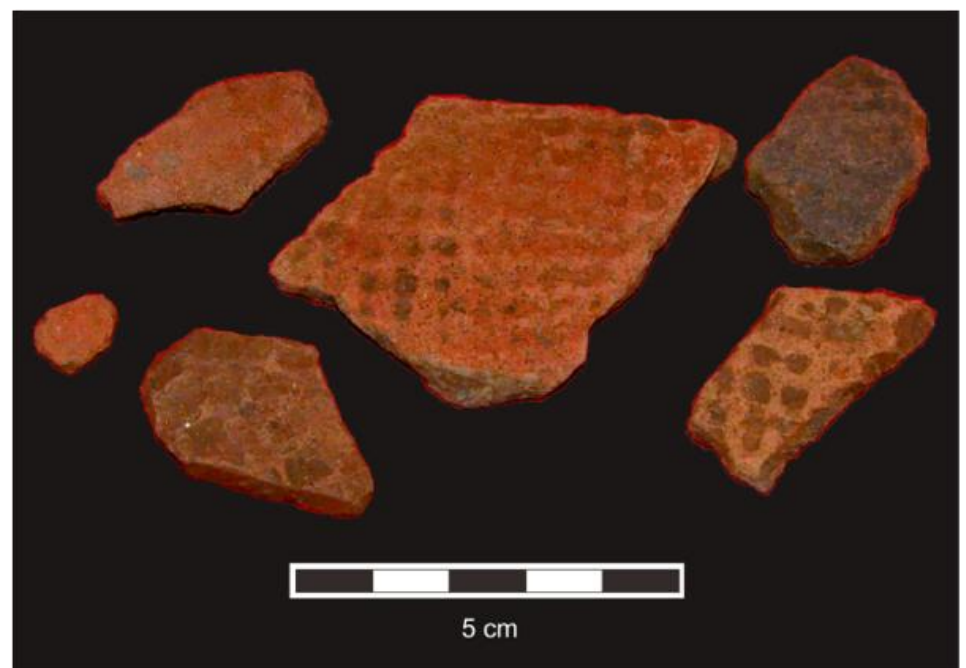

Figure 3. Several decorative rims from pottery sherds S15T14.

(Source: Regional Agency for Archaeological Research in D.I. Yogyakarta Province)

Observation results also show indication of the pottery firing technique. Pottery firing levels include oxidation, reduction, dehydration, and vitrification. The oxidation level is characterized by a completely evaporating carbon condition, so there is no residual carbon content. It makes the pottery sherds has brownish red colour. In addition, the cross-sectional colour part that look the same indicate an equal level of firing. The reduction level is characterized by the black remains in the middle part of pottery sherds. Black remains are derived from carbon trapped in pottery during the firing process. The vitrification level is characterized by the process when the mineral content and temper in the pottery melt together, so that the observed cross-section has the same colour and has a very fine temper resulted by high temperature firing process. The dehydration level is characterized by pottery sherds that do not go through firing process and only go through drying process under the sun (McKinnon, 1996).

Overall, the identification of pottery sherds showed that the most common found pottery sherds experienced oxidation firing levels. Oxidation firing level indicates the use of an open furnace, considering the material for lighting a fire still relies on oxygen (open firing). Pottery sherds also showed the level of reduction firing level that is using a closed place focusing on firing clay. In addition to oxidation and reduction firing levels, identification also indicates the presence of vitrification firing level. The vitrification firing level is found in modern pottery sherds. It is carried out with the use of kilns to obtain firing levels at high temperatures.

\section{Microscopic Analysis Results}

Petrographic analysis was conducted on six main samples and four comparison samples (see Table 2 and Table 3). Pottery samples are determined based on the results of macroscopic analysis of pottery sherds of Mulyosari Site. There were ten samples from four excavation boxes for petrographic analysis. The observation of thin-section petrographic analysis is horizontally divided into two, the inner and outer sides, while vertically divided into the right side and the left side. The difference between mineral density (inclusion percentage) seen in sample together with mineral sorting (the size of minerals in one field) is measured by percentage (see Table 4 and Table 5 ). The $10-50 \%$ percentage is low density category, while the percentage above $50 \%$ is high density category. The 
categories of pottery sorting levels are well sorted, poorly sorted, and very poorly sorted (Quinn, 2013).

Table 2. Karakteristik makroskopis sampel utama

\begin{tabular}{cll}
\hline No & Sample & Macroscopic characteristics \\
\hline 1. & S1T2-11 & Rim, scratch line motif, 2.5 YR 4/8 reddish brown \\
2. & S1T2-13 & Rim, stripe motif, 2.5 YR 4/8 reddish brown \\
3. & S14T14-15-a & Body, stripe motif, 2.5 YR 4/8 reddish brown \\
4. & S14T14-15-b & Body, stripe motif, 2.5 YR 4/8 reddish brown \\
5. & S15T14-13-a & Rim, plain, 2.5 YR 4/8 reddish brown \\
6. & S15T14-13-b & Body, tera/ stamped motif, 2.5 YR 4/8 reddish brown \\
\hline
\end{tabular}

Source: Anggara Nandiwardhana

Table 3. Macroscopic characteristics of the comparison sample

\begin{tabular}{lll}
\hline No & Sample & Macroscopic characteristics \\
\hline 1. & S1T2-6 & Rim, modern pottery, polished stripe motif, 2.5 YR 5/8 red \\
2. & S1T2-16 & Body, plain, 2.5 YR 5/6 red \\
3. & S14T13-4 & Body, plain, 2.5 YR 4/8 reddish brown \\
4. & S14T13-8 & Rim, stripe motif, 2.5 YR 4/8 reddish brown \\
\hline
\end{tabular}

Source: Anggara Nandiwardhana

Table 4. Mineral inclusion observed in the main samples

\begin{tabular}{llllllll}
\hline No & Sample & Quartz & Grog & Hematite & Opaque & Biotite & Calcite \\
\hline 1. & S1T2-11 & 29 & 0 & 7 & 48 & 23 & 15 \\
2. & S1T2-13 & 189 & 22 & 8 & 373 & & 0 \\
3. & S14T14-15-1 & 29 & 0 & 26 & 62 & 39 & 0 \\
\hline 4. & S14T14-15-2 & 27 & 0 & 11 & 35 & 14 & 0 \\
5. & S15T14-13-1 & 128 & 0 & 7 & 137 & 28 & 17 \\
6. & S15T14-13-2 & 68 & 0 & 5 & 80 & 10 & 0 \\
\hline
\end{tabular}

Source: Anggara Nandiwardhana

Table 5. Mineral inclusion observed in the comparison samples

\begin{tabular}{llllllll}
\hline No & Sample & Quartz & Grog & Hematite & Opaque & Biotite & Calcite \\
\hline 1. & S1T2-6 & 76 & 9 & 10 & 106 & 0 & 15 \\
2. & S1T2-16 & 63 & 0 & 2 & 35 & 0 & 0 \\
3. & S14T13-4 & 213 & 5 & 84 & 6 & 0 & 0 \\
4. & S14T13-8 & 42 & 25 & 9 & 41 & 65 & 11 \\
\hline
\end{tabular}

Source: Anggara Nandiwardhana

\section{S1T2-11 Sample}

The clay matrix in the S1T2-11 sample appears to have a colour composition between brown and black (see Table 6). The clay matrix on the outer side and the black inner side cause opaque minerals of similar colour unable to be observed through a microscope (see Figure 4). The discoloration is also an indication of differences in the stage of pottery making by involving the drying process in the sun and the firing process with a certain temperature. Mineral inclusion in this sample has irregular size with low density $(20 \%)$ and poorly sorted. This sample also shows the presence of voids. Void is a term used to refer to a kind of cavity 
or air chamber observed in a thin-section sample of pottery (Department of Archaeology University of York, 2000). The existence of voids in pottery samples indicates the possibility of making pottery with coiling techniques. Coiling techniques in the manufacture of pottery generally leave voids and streaks that are smooth and long.

Table 6. Inclusion percentage in 100x magnification of the main sample and comparison samples

\begin{tabular}{clll}
\hline No & Sample & Sortation level* & $\begin{array}{l}\text { Inclusion } \\
\text { Percentage** }\end{array}$ \\
\hline 1. & S1T2-11 & poorly sorted & 20 \\
2. & S1T2-13 & very poorly sorted & 30 \\
3. & S14T14-15-1 & very poorly sorted & 30 \\
4. & S14T14-15-2 & very poorly sorted & 30 \\
5. & S15T14-13-1 & very poorly sorted & 40 \\
6. & S15T14-13-2 & very poorly sorted & 30 \\
7. & S1T2-6 & well sorted & 10 \\
8. & S1T2-16 & poorly sorted & 20 \\
\hline 9. & S14T13-4 & poorly sorted & 30 \\
10. & S14T13-8 & very poorly sorted & 20 \\
\hline
\end{tabular}

Source: Anggara Nandiwardhana

* Sortation level determined based on Whitbread method

** The magnification performed is $100 \mathrm{x}$

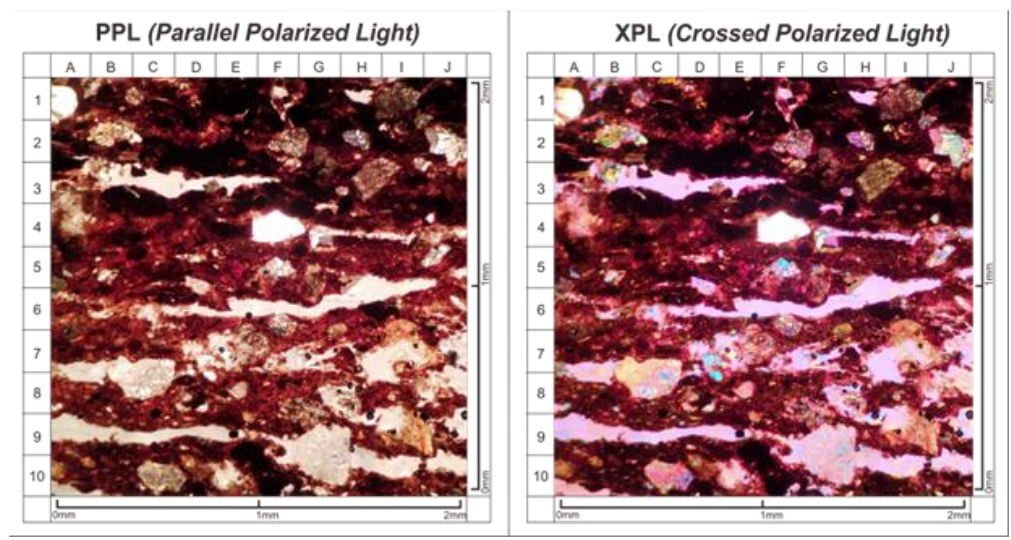

Figure 4. Cross-section of S1T2-11 Samples. A1: quartz, E2: opaque, H9: void, C4: hematite (Source: Regional Agency for Archaeological Research in D.I. Yogyakarta Province)

\section{S1T2-13 Sample}

The clay matrix in the S1T2-13 sample shows a gradation of brown colour from dark to light. Mineral inclusion in this sample tends to be low density with a percentage of $30 \%$ and very poorly sorted (see Table 7). Observed mineral inclusion consists of quartz, calcite, grog, biotite, hematite, and opaque minerals in relatively small, unidentified sizes (see Figure 5). Grog is a term used to refer to the crushing of pottery or burnt clay added to clay as temper (Department of Archaeology University of York, 2000). The presence of sandstone in observed inclusions of relative size is likely to be a material or temper that is deliberately added to strengthen the pottery material. This sample has a streak that looks elongated and convex to the inner side, where the clay matrix is very solid. It shows indications of pottery making with pressing techniques. 
Table 7. Sortation level of the entire pottery sample.

\begin{tabular}{llll}
\hline No & Sample & Sortation level & Sample type \\
\hline 1. & S1T2-6 & well sorted & Comparison \\
\hline 2. & S1T2-11 & poorly sorted & - \\
\hline 3. & S1T2-16 & poorly sorted & Comparison \\
\hline 4. & S14T13-4 & poorly sorted & Comparison \\
\hline 5. & S1T2-13 & very poorly sorted & - \\
\hline 6. & S14T14-15-1 & very poorly sorted & - \\
\hline 7. & S14T14-15-2 & very poorly sorted & - \\
\hline 8. & S15T14-13-1 & very poorly sorted & - \\
\hline 9. & S15T14-13-2 & very poorly sorted & - \\
\hline 10. & S14T13-8 & very poorly sorted & Comparison \\
\hline
\end{tabular}

Source: Anggara Nandiwardhana

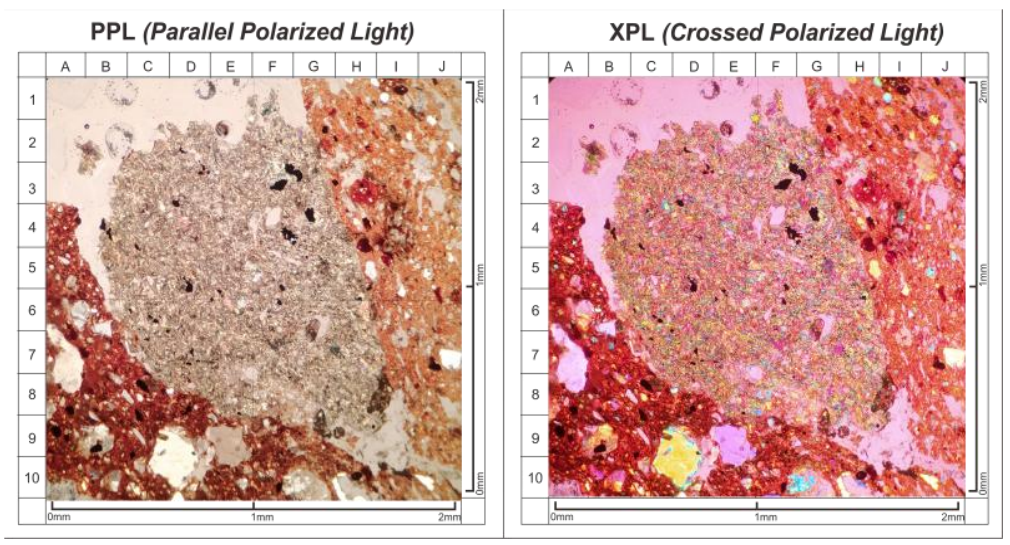

Figure 5. Cross-section of S1T2-13 Samples. E5: sandstone, H3: hematite. (Source: Regional Agency for Archaeological Research in D.I. Yogyakarta Province)

\section{S14T14 15-a Sample}

The clay matrix on the S14T14 15-a sample has a black colour both on the outer side and on the inner side. The dark colour of the clay matrix causes difficulties in the identification of opaque minerals within the clay matrix. Mineral inclusion in this pottery sample has a low density (30\%) and very poorly sorted (see Table 6). The condition of the clay line is almost flat and invisible, so it cannot be determined which pottery making techniques it uses. But from the presence of voids observed in the clay matrix shows the possibility of making pottery with pressing techniques. Pressing techniques involve the process of pressing when forming pottery. The pressure of such techniques generally leaves voids. The void shape tends to be elongated and convex from the outer side towards the inner side. The shape of the void is due to the pressure from the finger during the pottery making process (Quinn, 2013). The dark colour of the clay matrix indicates the possibility that the clay used comes from a location close to the water source. In addition, there is a visible inclusion of hematite minerals in the void. The presence of voids in the matrix of clay filled with hematite minerals is likely due to temperature changes (see Figure 6). 


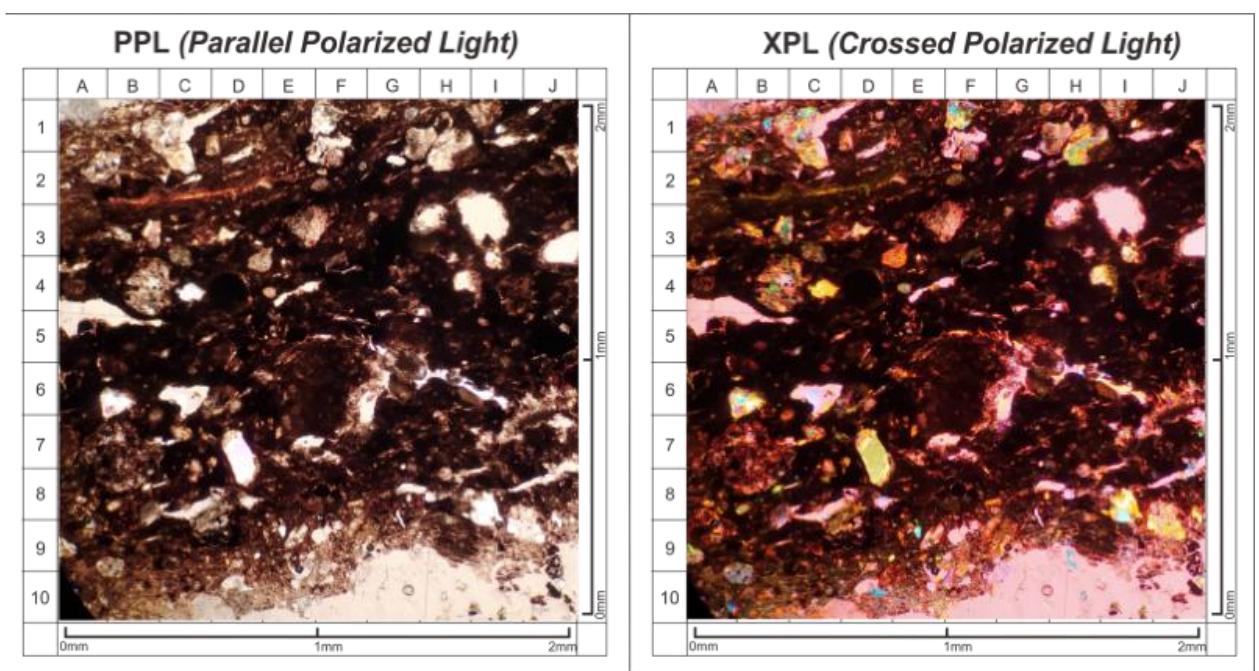

Figure 6. Cross-section of S14T14 15-a Samples D2: hematite, H8: void I3: quartz (Source: Regional Agency for Archaeological Research in D.I. Yogyakarta Province)

\section{S14T14 15-b Sample}

The clay matrix of the S14T14 15-b sample has a dark brown colour in the center. Mineral inclusion in this sample has a low density percentage $(30 \%)$ with very poorly sorted condition. Mineral inclusions observed include quartz, opaque minerals, hematite, and calcite with relatively small sizes (see Figure 7).
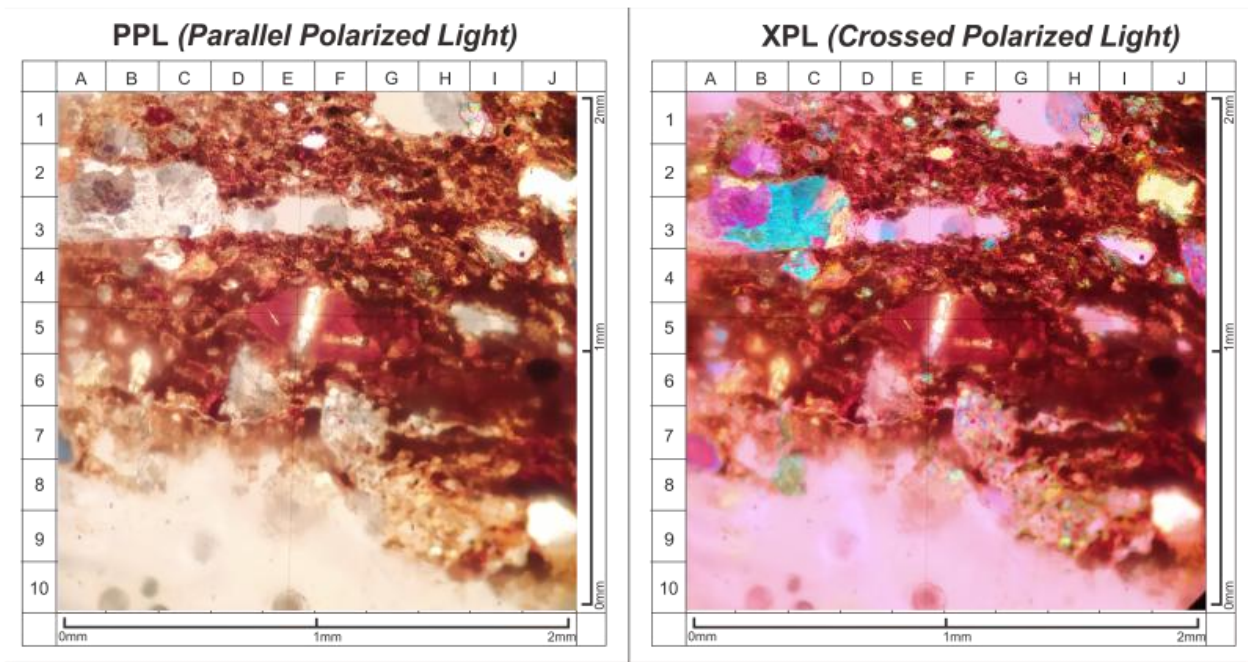

Figure 7. Cross-section of S14T14 15-b Samples. H1: biotite F5: hematite, J6: opaque

(Source: Regional Agency for Archaeological Research in D.I. Yogyakarta Province)

\section{S15T14 13-a Sample}

Mineral inclusion in the 15T14 13-a samples shows low density (40\%) with very poorly sorted levels. The clay matrix indicates a black gradation from dark to light from the outer side to the inner side (see Figure 8). It appears that the voids in this sample form thin crack lines although not thoroughly. Mineral inclusion in these samples is dominated by quartz of various sizes. Condition of the streak in this sample is so smooth that it is barely visible. Therefore, the pottery making technique cannot be determined. 


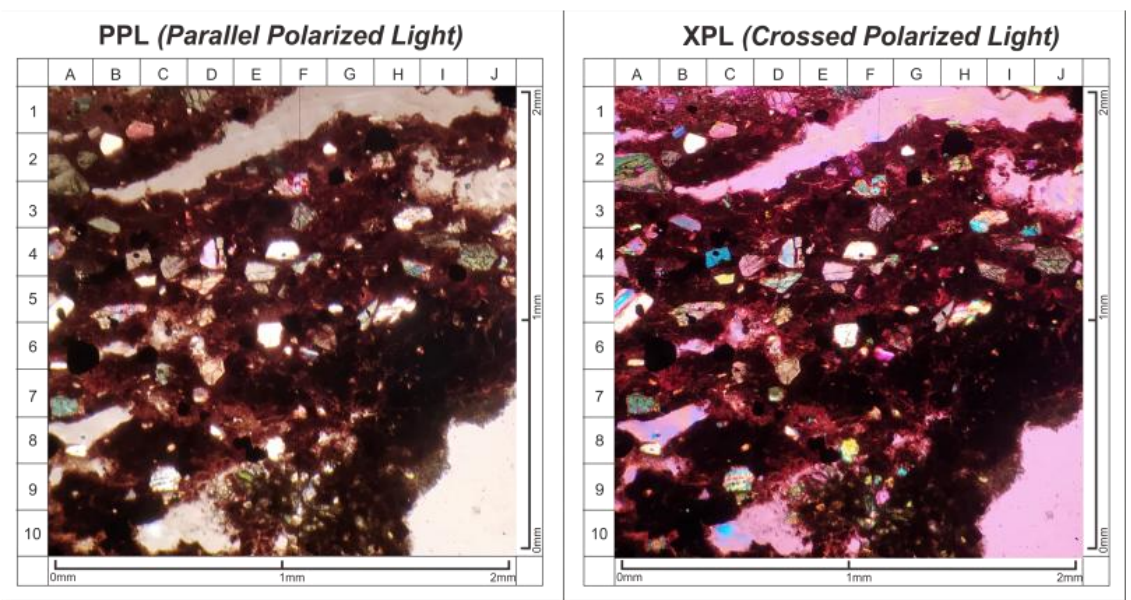

Figure 8. Cross-section of S15T14 13-a Samples A5: quartz, D10: void.

(Source: Regional Agency for Archaeological Research in D.I. Yogyakarta Province)

\section{S15T14 13-b Sample}

The clay matrix in this sample shows a less significant colour gradation. The observed color gradation is dark brown to light brown from the outside to the inner side (see Figure 9). Mineral inclusion in this pottery sample shows a low density rate $(30 \%)$ and very poorly sorted. Mineral inclusion in the form of quartz is relatively large. The clay line (streak) in this pottery sample can be observed, but the condition of the clay line is not enough to determine the pottery making technique.

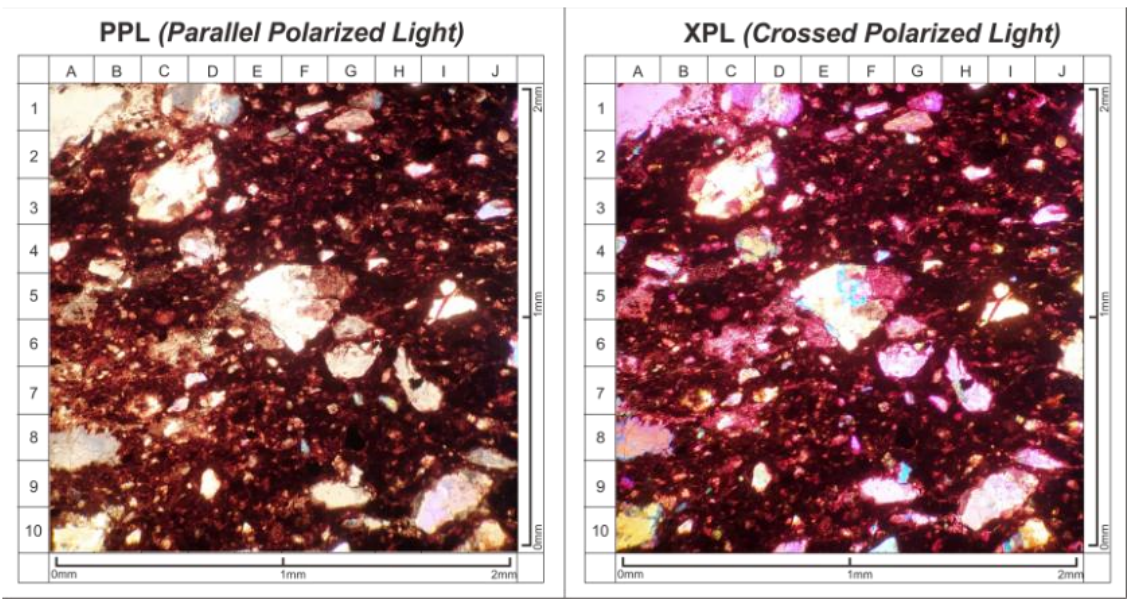

Figure 9. Cross-section of S15T14 13-b Samples. G8: opaque, C5: hematite, E5: quartz. (Source: Regional Agency for Archaeological Research in D.I. Yogyakarta Province)

\section{S1T2-6 Sample}

The clay matrix in the S1T2-6 sample showed a gradation of brown color from dark to light. The clay matrix is dark brown on the outside and gets lighter on the inside (see Figure 10). Mineral inclusion in pottery samples has a low density $(10 \%)$ and belongs to the category of well sorted. This indicates that the material used in the pottery making undergoes a sieving process. Sieved material has a tendency to have good sorting condition (Quinn, 2013). This samples appears to have inclusions of hematite and grogs with a relatively large size. This sample has a smooth, barely observable streak, and a solid clay matrix. These characteristics indicate the possibility that the pottery is made with spinning wheel techniques. 


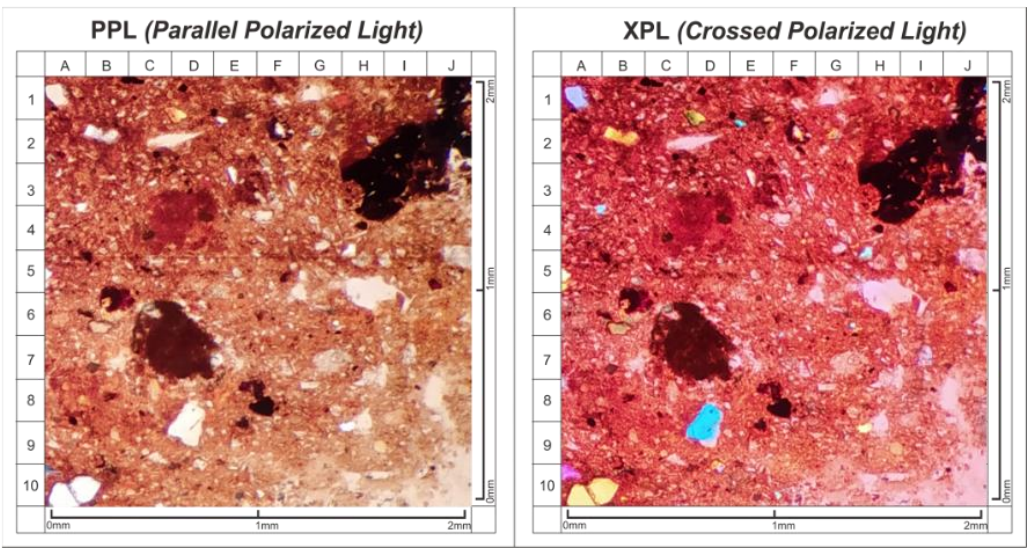

Figure 10. Cross-section of S1T2-6 Comparison Samples. C4: Grog, F8: opaque, C6: hematite (Source: Regional Agency for Archaeological Research in D.I. Yogyakarta Province)

\section{S1T2-16 Sample}

The clay matrix in the S1T2-16 sample has a gradation between brown to black from the outer side to the inner side (see Figure 11). Mineral inclusion in this pottery sample has irregular size with low density $(20 \%)$ and poorly sorted condition. This gives an indication that pottery making materials such as sand or soil do not undergo sieving process. The inclusion found or dominant in this sample are quartz of varying sizes and has amphibolic forms (amphibole). The blackish color of the clay matrix makes opaque minerals of the same color are not observable through microscopes. The streak on this pottery sample is barely visible so the pottery making technique cannot be determined.

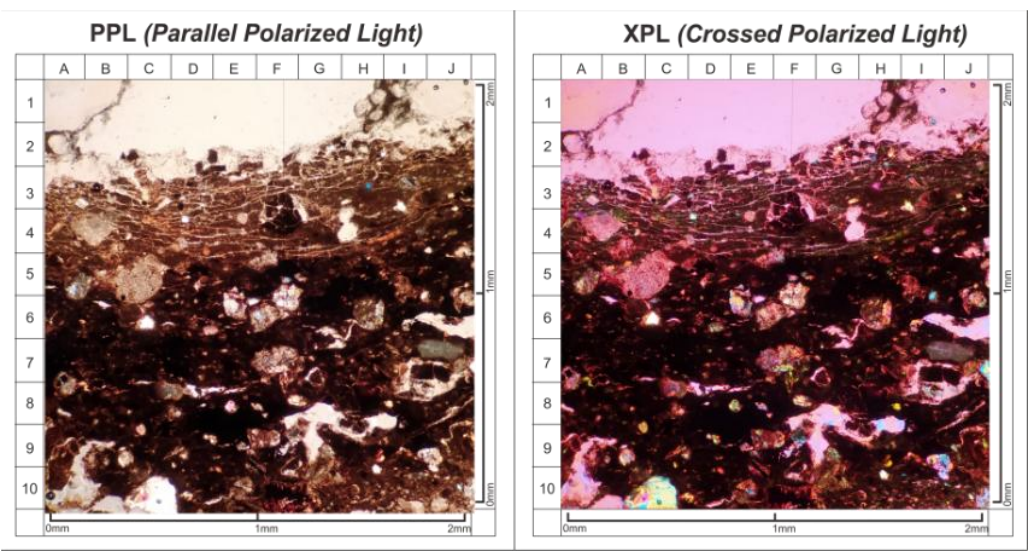

Figure 11. Cross-section of S1T2-16 Samples. C6: quartz, D5: opaque, I5: hematite. (Source: Regional Agency for Archaeological Research in D.I. Yogyakarta Province)

\section{S14T13-4 Sample}

The clay matrix of the S14T13-4 sample appears to have a cavity that resembles pores (see Figure 12). This is likely because during the process of making a thin-section, the sample is not completely dry. The inclusion observed are dominated by relatively small quartz. The clay matrix has a gradation of brown colour from dark to light from the outer side to the inner side. Mineral inclusion tends to be low density (30\%) and poorly sorted (see Table 6). In addition to minerals, there are grogs that indicate a possibility of additional materials (temper) in the form of crushed pottery sherds. The pottery sherds are crushed and mixed with other pottery materials. The presence of grog can also indicate a different level of firing result from other inclusion materials, so it is as if the grog forms a separate inclusion. The clay line (streak) in this pottery sample 
is almost flat or not observable, so the pottery making technique cannot be determined.

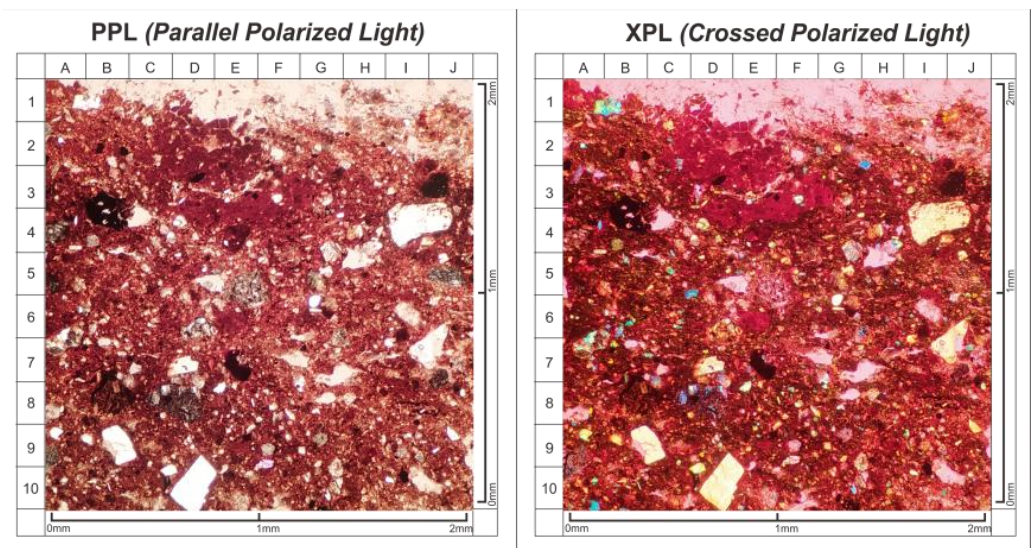

Figure 12. Cross-section of s14T13-4 Samples, E3: grog B4: opaque, D10: quartz, I3: hematite. (Source: Regional Agency for Archaeological Research in D.I. Yogyakarta Province)

\section{S14T13-8 Sample}

The clay matrix in the S14T13-8 sample shows a gradation of brown color from dark to light from the outer to the inner side (see Figure 13). Material inclusion in this sample has a low density of $20 \%$ with a very poorly sorted level. There are grogs in inclusions that tend to be darker than clay matrix. The clay matrix appears to have cavities that resemble pores. This is likely because during the process of making a thin-section, the sample is not completely dry. The dominant inclusion in this sample consist of calcite and quartz with a relatively small size. The streak in this sample is almost flat or not observable, so the pottery making technique cannot be determined.

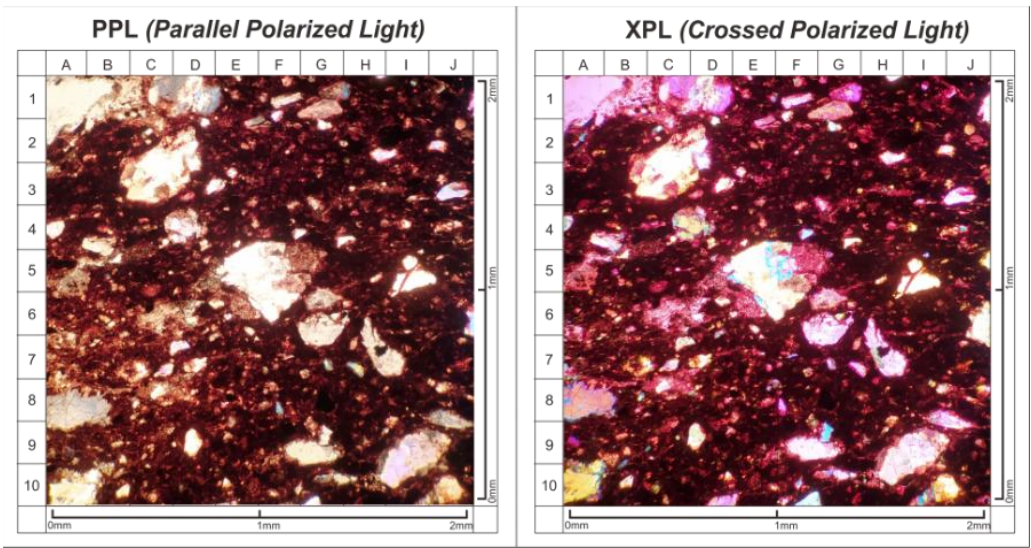

Figure 13. Cross-section of S14T13-8 Samples. C9: grog H9: hematite. (Source: Regional Agency for Archaeological Research in D.I. Yogyakarta Province)

\section{DISCUSSION}

The pottery making process can be done by mixing clay with some additional materials (temper). Additional materials commonly used include sand, soil, roots, pottery sherds, shells, and minerals (Nandiwardhana, 2017). Petrographic analysis shows the results in the form of mineral inclusion and sorting level (Fatmarani, 2016). These minerals include opaque, hematite, biotite, quartz, and calcite. Quartz minerals are found in all pottery sample. The observed quartz minerals are relatively large and irregular in size, indicating the possibility that the temper used as an addition comes from the highlands. 
Minerals derived from the highlands are generally amphibolic.

Pottery making involves firing techniques in a certain temperature. It is difficult to determine the best temperature in the pottery making process. Beals and Hoijer stated that clay can be burned at $400^{\circ} \mathrm{C}$ (Atmosudiro, 1984). Accordingly, Gordon Childe states that clay achieves the best firing level at $400^{\circ} \mathrm{C}$. At these temperatures the chemical composition of the clay can change (Atmosudiro, 1984).

Hematite minerals are observed in all pottery samples indicating the possibility of firing processes at a certain temperature. Hematite can be found in soil types containing minerals rich in iron $(\mathrm{Fe})$ and naturally are black colour. The firing process with a certain temperature converts hematite into a different colour that is from black to red (feral oxide reaction). Meanwhile, drying process can change the color of hematite from black to orange and yellow. The hematite arises due to the firing process in high temperatures (referring to the firing temperature in the pottery making process). The firing process that forms clay and high iron soil oxidized to form hematite (Quinn, 2013).

Opaque minerals are found in all pottery samples, while biotite minerals are not. Biotite minerals are found in pottery samples S14T13-8, S1T2-11, S14T1415-1, S14T14-15-2, S15T14-13-1, S15T14-13-2. Biotite minerals are usually found in a sandy soil type. The absence of biotite in some pottery samples does not mean that the pottery does not use sand as an additional material (temper). It is possible that the differences in the sand filtration process causes the biotite to appear or not. The presence of calcite minerals in a number of pottery samples, S1T2-6, S14T14-8, S1T2-11, S15T14-13-1, indicates the possibility that the source of pottery-making materials comes from soil types with high calcium levels.

Several clay matrix appear to have a grog inclusion that indicates the use of clay or pottery sherd mixed into the clay paste during the process of pottery making (reuse). Evidence of grog as temper is seen from the clay line (streak) and the colour of the clay matrix. The absence of grog inclusions in some samples suggests that not all pottery samples used pottery sherds as temper.

Mineral sortation in pottery samples is categorized into well sorted, poorly sorted, and very poorly sorted (see Table 6). Well sorted pottery sample is S1T2-6, poorly sorted pottery samples are S1T2-11, S1T2-16, S14T13-4; very poorly sorted pottery samples are S1T2-13, S14T14-15-1-2, S15T14-13-1-2, and S14T13-8. Well sorted condition is assessed from the size of mineral inclusions seen in thin-section when compared to clay matrix that have an almost even size. Mineral inclusions with poorly sorted condition is seen from irregular size and almost scattered in the whole clay matrix. Very poorly sorted condition is seen from mineral inclusions of very irregular sizes. Large mineral inclusions are minerals such as biotite and quartz.

The percentage of mineral inclusions seen in the clay matrix was observed and represented on the Wentworth scale (Quinn, 2013). All pottery samples that have a sortation rate between $10-50 \%$ fall into the low density category, while pottery samples that have a sortation rate above $50 \%$ fall into the high density category. The degree of sortation indicates intentional or accidental mineral inclusion mixed in pottery sherds and shows the porosity of the pottery additional material (Quinn, 2013).

The firing level in pottery making can be seen by the naked eye (macroscopic) at the time of samples selection. Pottery samples that have low firing levels can be observed from the density of the clay matrix. Pottery that has a low firing level (possibly below $400^{\circ} \mathrm{C}$ ) indicates that it is an ancient pottery. 
Meanwhile, the indication of modern pottery found in S1T2-6 sample. It has firing level at vitrification, reaching temperatures of $400^{\circ} \mathrm{C}$ or even more. It also has decorative patterns using incision and polished on the surface. In addition, it have a well sorted condition of mineral sortation.

Comparison samples S1T2-16, S14T13-4, S14T13-8 showed no indication of firing at vitrification level. Instead, they have reduction firing level seen from the texture of clay on cross section that is not subtly attached. Exceptionally, the subtle surface characteristics of the pottery sample indicate that the S1T2-16 sample may have come from modern pottery sherds. The surface texture of macroscopically observed pottery samples indicates the possibility of pottery making with pressing techniques.

Pottery samples shows a black clay matrix include S14T14-15-a, S15T1413-a and S15T14-13-b. S14T14-15a show reduction firing levels, while S15T14-13a \& S15T14-13-b show oxidation firing levels. Oxidation firing levels are seen in the middle of cross section that is black, exceeding the outer color of the pottery. Meanwhile, some samples showed pressing while forming techniques. Traces of the specific pottery making techniques are found in the form of voids such as cavities or air chambers in samples S14T14-15-a and S15T14-13-b.

The observations also showed a streak on the clay matrix (Quinn, 2013). Streak is a clay line that can be observed in thin section samples. The clay lines appears in clay matrix as a result of pottery making techniques. Each pottery making technique will likely produce a different clay matrix. Spinning wheel techniques generally form elongated clay lines but tend to be tighter compared to coiling techniques. When it comes to spinning wheel techniques, distinction will also be seen from slow-pace spinning wheels and fast-pace spinning wheels. Fast-pace spinning wheels will result in tighter, almost smoother or less visible clay lines. Coiling techniques generally form elongated clay lines. Pressing or squeezing techniques generally form clay lines that tend to be shorter compared to spinning wheel and coiling techniques. Somehow, it usually forms the void from finger pressure during the pottery making process (McKinnon, 1996).

Mineral inclusions found in pottery tempers indicate the possible location of the material source. The location of material source is strongly related to the geological condition of the researched area. In general, the researched area and its surroundings belong to the Southern Mountain Zone (Bemmelen, 1949). The rocks have appeared in tertiary times, so the condition of the rocks has been perfectly classified. The condition of the rocks significantly affects the form of reliefs that are not only rough, but also complicated. This is in contrast to the north relief of the Southern Mountain Zone which are smooth due to the covering of volcanic material on the surface. Here is the formations division in the Geological Map of Jember Sheet (Sartohadi, 2014):

1. Alluvium (Qa): stones, gravel, sand, and mud.

2. Kalibaru Formation (Qvat): Breccia, lava, conglomerate, sandstone, tufa, and tuff.

3. Argopuro tuff (Qpvk): lithic tuff, ash tuff, and lava tuff.

4. Puger Formations (Tmp): bronze limestone sided breccia limestone, and tufa limestone.

5. Mandiku Formation (Tmm): Volcanic breccia and breccia tuff with andesite, and basalt sided tuff.

6. Breakthrough rocks (Tmi): granodiorite, diorite, and dasite.

7. Sukamade Formation (Toms): clay sided silt rocks, and sandstone. 
8. Merubetiri Formation (Tomm): an alternation of volcanic breccia, lava, and tuff propiliated.

9. Batu Ampar Formation (Tomb): an alternation of sandstone tuff-sided claystone (pyroclastic rocks containing volcanic dust), breccia, and conglomerate.

10. Members of Merubetiri limestone Formation (Tml): limestone, tuff limestone, and marlstone.

In particular, the researched area is composed of four constituent rock formations on the regional geological map of Jember and geomorphologically in the form of structural land of Merubetiri Complex (Sartohadi, 2014). This complex has a very different genesis than the surrounding land formation. The four constituent rock formations are the Sukamade Formation, Merubetiri Formation, Batu Ampar Formation, and Members of Merubetiri limestone Formation (see Figure 14).

Quartz minerals are commonly found in volcanic breccia rocks. Calcite is commonly found in limestone types. Biotite is commonly found in sandstone deposits (sedimentary rocks). Opaque minerals are likely derived from rockes that are ferromagnetic, ilmenite, pyrite, magnetite, and graphite (Barker, 2014). Based on the identification of these minerals, the possible raw material sources used in the pottery making is in the geological formations of the researched area (see Table 8). The location of material source is not far from the minerals found in rock formation. Geologically, the range of the material source location area may be close to the current site location, but it may also be far from the current site location considering the area of geological formations in Merubetiri and surrounding areas.

Table 8. Map Information of Possible Locations of Pottery Making Materials Source in Mulyosari Site

\begin{tabular}{|c|c|c|c|c|}
\hline \multirow[b]{2}{*}{ No } & \multicolumn{2}{|l|}{ Geology } & \multicolumn{2}{|r|}{ Geomorphology } \\
\hline & $\begin{array}{l}\text { Formation } \\
\text { Code }\end{array}$ & $\begin{array}{l}\text { Geological Formation of Jember } \\
\text { Sheet }\end{array}$ & Code & Merubetiri Complex Structure \\
\hline 1. & Tomb & $\begin{array}{l}\text { Batuampar Formation, } \\
\text { sandstone and clay tuff } \\
\text { (pyroclastic rocks containing }\end{array}$ & $\mathrm{H} 1 \mathrm{~S} 19$ & $\begin{array}{l}\text { Upper Slope of Volcanic Breccia } \\
\text { Structural Hills Batuampar } \\
\text { Formation }\end{array}$ \\
\hline 2. & & $\begin{array}{l}\text { volcanic dust), breccia, and } \\
\text { conglomerate. }\end{array}$ & $\mathrm{H} 2 \mathrm{~S} 10$ & $\begin{array}{l}\text { Central Slope of Claystone } \\
\text { Structural Hills Batuampar } \\
\text { Formation }\end{array}$ \\
\hline 3. & & & H1S46 & $\begin{array}{l}\text { Upper Slope of Andesite Lava } \\
\text { Structural Hills Batuampar } \\
\text { Formation }\end{array}$ \\
\hline 4. & Tomm & $\begin{array}{l}\text { Merubetiri Formation, an } \\
\text { alternation of volcanic breccia, } \\
\text { lava, and tuff propiliated. }\end{array}$ & & \\
\hline 5. & Toms & $\begin{array}{l}\text { Sukamade formation, claystone } \\
\text { sided with silt rocks and } \\
\text { sandstone. }\end{array}$ & $\mathrm{H} 1 \mathrm{~S} 13$ & $\begin{array}{l}\text { Sukamade Upper Slope of } \\
\text { Sandstone Structural Hills } \\
\text { Sukamade Formation }\end{array}$ \\
\hline 6. & & & $\mathrm{H} 2 \mathrm{~S} 11$ & $\begin{array}{l}\text { Central Slope of Claystone } \\
\text { Structural Hills Sukamade } \\
\text { Formation }\end{array}$ \\
\hline 7. & Tml & $\begin{array}{l}\text { Members of Merubetiri } \\
\text { limestone Formation, limestone, } \\
\text { tuff limestone, and marl. }\end{array}$ & & \\
\hline
\end{tabular}

Source: Jember Sheet Geological Map, Sartohadi, 2014 


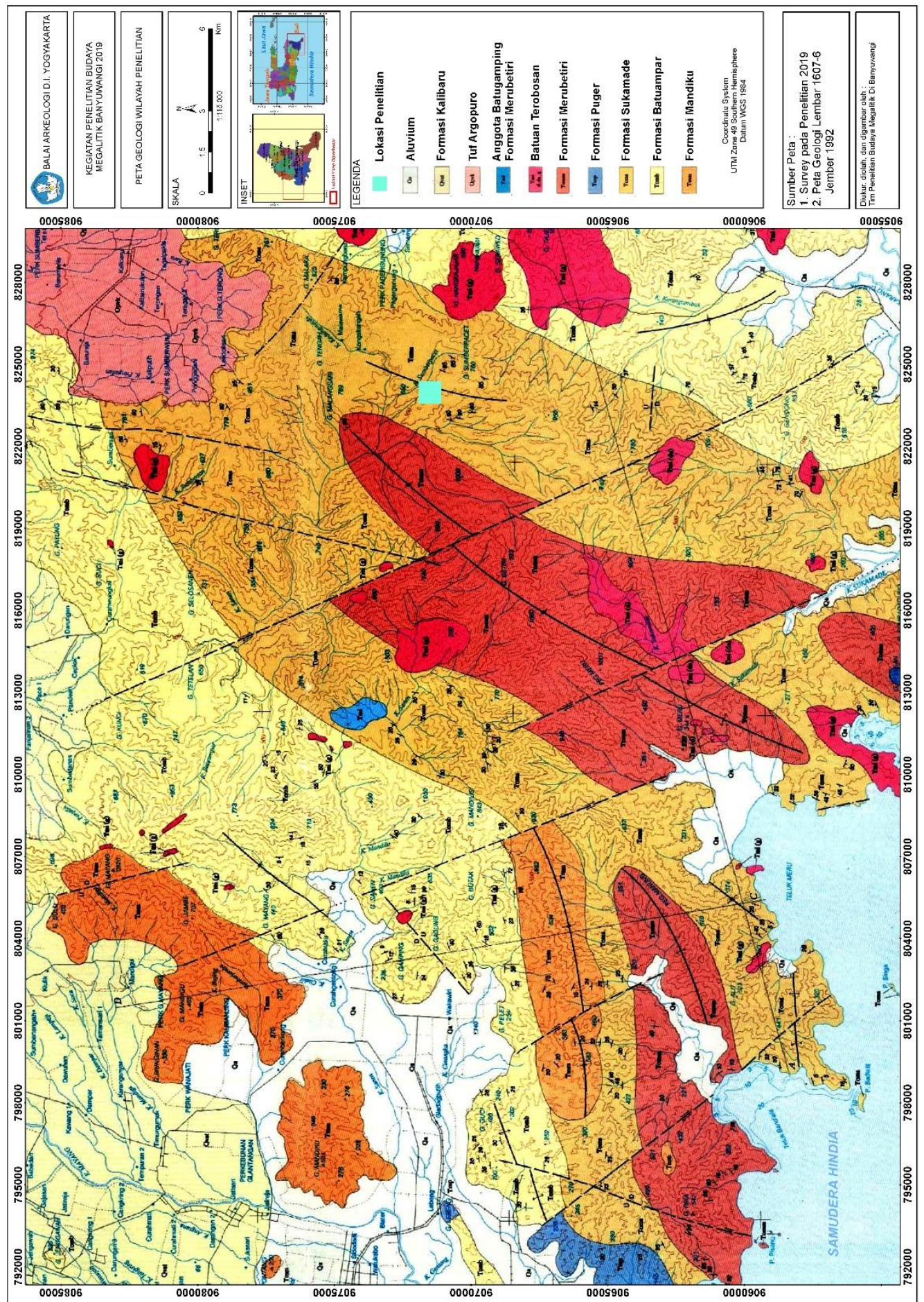

Figure 14. Geological map to show the types of soil formations in the researched area. Source: Taniardi et al., 2019

\section{CONCLUSION}

Petrographic analysis conducted on several samples pottery sherds at the Mulyosari Site simply showed the percentage of minerals. As seen from the presence of minerals around Mulyosari, there is a possibility that pottery found was produced from around the site. The location of Mulyosari Site, which is near Mount Raung, provides mineral resources and diverse soil variations of volcanic materials.

In addition, the results of petrographic analysis for pottery are very 
important in the identification of mineral composition based on microscopic aspects. The results of this analysis were able to show that the raw material sources used in the pottery making is in the geological formations of the researched area. Geological data suggests that the range of the material source location area may be close to the site's current location. These results are known from the point counting of minerals in pottery sherds. The results of petrographic analysis become the basis or starting point for geochemical analysis that can show the clay-forming and temper elements more specifically.

In general, the results of macroscopic and microscopic analysis of pottery sherds shows the technology and possible location of the raw material sources. The technologies used in the Mulyosari Site pottery making are spinning wheels, pressing while forming, and coiling. Meanwhile, the possible location of the raw material sources within the range of the site area leads to indications that the pottery of the Mulyosari Site is made locally. However, research with more in-depth analysis is needed to determine the distribution flow or the possibility of local and intra regional trade. A more in-depth analysis requires comparison pottery samples from megalithic sites in Banyuwangi and surrounding areas, as well as modern pottery samples from today's potters.

\section{AUTHOR DECLARATION}

All Authors contributed to the creation of this manuscript, and served equally as as primary contributors. Putri Novita Taniardi writes the research history of Megalithic Culture at Mulyosari Site. Anggara Nandiwardhana conducted the petrographic analysis and writes the analysis result. Maulana Ainul Yaqin writes the geological condition at Mulyosari Site. Citra Iqliyah Darojah writes the application of petrographic analysis at prehistoric sites in Indonesia. The manuscript has been read and approved by all authors. The order of authors listed in the manuscript has been approved by all named authors. All authors did not receive funding for the creation of this manuscript. All authors confirm that there are no known conflicts of interest associated with this publication and there has been no significant financial support for this work that could have influenced its outcome. All authors adhered to the Copyright Notice set by Berkala Arkeologi.

\section{ACKNOWLEDGEMENT}

The authors thanks the Department of Archaeology, Faculty of Cultural Sciences, Universitas Gadjah Mada, for providing laboratory facilities for petrography analysis. The author also expresses her gratitude to Dr. Dwi Yani Yuniawati who has given guidance on writing this article. Last, the Regional Agency for Archaeological Research in D.I. Yogyakarta Province Research Team and all those who helped write this article. 


\section{REFERENCES}

Atmosudiro, S. (1984). Studies on ceramics, notes on the tradition of pottery making in the Region of Kasongan, Regency of Bantul, Yogyakarta. Pusat Penelitian Arkeologi Nasional, Proyek Penelitian Purbakala, Departemen $\mathrm{P}$ dan $\mathrm{K}$.

Barker, A. (2014). A key for identification of rock-forming minerals in thin-section. Taylor and Francis Group.

Bemmelen, R. W. Van. (1949). The geology of Indonesia vol. II: general geology of Indonesia and adjacent archipelagoes.

Department of Archaeology University of York. (2000). Petrology glossary. Internet Archaeology

https://intarch.ac.uk/journal/issue9/glossary.htm\#Temper

Fatmarani, S. (2016). Analisis daerah asal gerabah di Situs Topo dan Mareku, Pulau Tidore, Maluku Utara berdasarkan analisis bentuk, hiasan dan petrografi. Gadjah Mada.

Gede, I. D. K. (2013). Misba dalam masyarakat Alor: kajian bentuk dan fungsi. Forum Arkeologi, 26(3), 181-194.

Kasnowihardjo, G. (2012). Teknologi gerabah Situs Ranu Bethok dan Ranu Grati: "sebuah kajian berdasarkan analisis petrografi." Berkala Arkeologi, 32(2), 109-124. https://doi.org/10.30883/jba.v32i2.51

Kusumawati, A. (2011). Kemajemukan tradisi megalitik di Indonesia. Forum Arkeologi, 24(3), 211-223. https:// doi.org/10.24832/fa.v24i3.299

Mahirta. (2003). Human occupation on Rote and Sawu Islands, Nusa Tenggara Timur. Australian National University.

Mc Kinnon, E. E. (1996). Buku panduan keramik.

Nandiwardhana, A. (2017). Analisis teknologi dan petrografi gerabah pada Situs Tron Bon Lei, Desa Lerabaing, dan Gua Tabubung di Pulau Alor. Universitas Gadjah Mada.

Orton, C., Tyers, P., \& Vince, A. (1993). Pottery in archaeology. Cambridge University Press.

Ownby, M. F., Giomi, E., \& Williams, G. (2017). Glazed ware from here and there: Petrographic analysis of the technological transfer of glazing knowledge. Journal of Archaeological Science: Reports, 16, 616-626. https://doi.org/10.1016/j.jasrep.2016.04.019

Quinn, P. S. (2013). Ceramic petrography, the interpretation of archaeological pottery $\mathcal{E}$ related artefacts in thin section. Berforts Information Press, Oxford.

Sartohadi, J. (2014). Bentang sumberdaya lahan Kawasan Gunung Ijen dan sekitarnya. Laboratorium Geografi Tanah Fakultas Geografi. UGM.

Solheim, W. G. I. (1990). Earthenware pottery, the T'ai and the Malay. Asian Perspective, 29(1),

25. https://www.semanticscholar.org/paper/Earthenware-Pottery\%2Cthe-T\%27ai-and-the-MalaySolheim/ae5602deba4b3085a39cd0181e30f9d6aa667941

Taniardi, P. N., Alifah, Wibowo, H., Purnamasari, R., Darojah, C. I., Yaqin, M. A., Saputro, B. I., Wibisono, M. W., Fuadillah, G. A., Mudjiono, \& Asmaranatha, P. B. A. (2019). Laporan Penelitian Arkeologi: Budaya megalitik di Banyuwangi dalam konteks persebaran budaya megalitik Jawa Timur. 
This page was left intentionally blank. 